Int. J. Morphol.,

30(1):217-221, 2012

\title{
Morphometric Changes in Talus of Club Foot - A Gross Observation in Human Foetuses
}

\author{
Cambios Morfométricos en Talus del Pie Zambo, \\ una Observación Macroscópica en Fetos Humanos
}

Fazal-ur-Rehman \& Nafis A. Faruqi

\begin{abstract}
FAZAL-UR-REHMAN \& FARUQUI, N. A. Morphometric changes in talus of club foot - a gross observation in human foetuses. Int. J. Morphol., 30(1):217-221, 2012.

SUMMARY: Both the feet of six human foetuses of different age groups having unilateral club feet, were dissected for morphological study. Six morphometric parameters considered for comparing gross anatomical changes in normal and deformed feet, were 1-Maximum length of the talus, 2-Longitudinal dimension of head of talus, 3-Anterior trochlear breadth, 4-Maximum medial talar height, 5-Talar neck and calcaneal angle, 6-Talocalcaneal angle. All the foetuses with congenital club feet have almost similar deformity of foot skeleton. The gross anomalies observed were the smaller size of club foot talus and increased medial and planter deviation of a stunted, misshapen head and neck region. A medial plantar subluxation of the navicular bone with a consequent deformity of the articular facets of the talar head was also observed. Uniformity and consistency of anatomical abnormalities were striking features in present study.
\end{abstract}

KEY WORDS: Club foot; Talus; Morphometry; Human foetuses.

\section{INTRODUCTION}

Congenital club foot is a condition in which one or both feet are twisted into an abnormal position at birth. This condition is also known as talipes. Although it is a common deformity, yet its etiology remains obscure. Genetic factors appear to dominate as the incidence of the deformity among the first degree relative is twenty to thirty times higher than that in the normal population. Since the condition starts in the first trimester of pregnancy, the abnormality is quite well established at birth. Three general categories of congenital club feet have been recognized. 1. Those associated with neuromuscular diseases such as myelodysplasia or arthrogryposis. 2 . Those associated with multiple congenital anomalies with a normal neuromuscular system. 3. Those defined as idiopathic when club foot is the only anomaly. Within the latter two categories, the deformity has been considered secondary to tarsal developmental anomalies (Irani \& Sherman, 1972) or arrests (Bohm, 1929; Keith, 1948), subclinical neuromuscular abnormalities and muscular imbalance (Bechtol \& Mossman, 1950; Flinchum, 1953), tendinous malposition (Stewarts, 1951) or extrinsic mechanical pressure (Browne \& Sydney, 1934; Parker \& Shattock, 1884). The major evidence for intrauterine mechanical factors evolves from the work of (Dunn, 1972, 1976) who found an increased incidence of foot deformities in first pregnancy, breach presentation and pregnancies complicated by oligohydroamnions and concluded that all foot deformities including club foot were caused by intrauterine molding. In terms of etiology there has been fairly consistent recognition of abnormalities of talus, in particular of head and neck region (Adams 1852, 1855; Irani \& Sherman; Kaplan, 1972; Keith; Siegel, 1974; Stewart). The talar abnormalities have been found in all three categories of club foot, raising the question as to whether they are primary or secondary. A difference of opinion exists. Some presumed that there was defective formation of the cartilage analage that was, a germ plasm defect (Irani \& Sherman). Others postulated that the foot normally assumed a so called physiological club foot position of equines, supination and adduction during the second embryonic month and the eventual club foot deformity represented a developmental arrest with the early position persisting (Bohm; Keith). The aim of the study was to find out the possible cause of club foot by direct observation on dissected human foetuses. 


\section{MATERIAL AND METHOD}

Feet from six human foetuses of different ages with unilateral club foot; were fixed in $10 \%$ formline solution. No other skeletal deformities were observed in foetuses selected for the study. Six morphometric parameters were taken for comparable gross anatomical changes in normal and deformed feet, i.e., 1-Maximum length of the talus, 2Longitudinal dimension of head talus, 3-Anterior trochlear breadth, 4-Maximum medial talar height, 5-Talar neck and calcaneal angle, and 6-Talocalcaneal angle. Soft tissues were carefully removed in diseased feet as well as normal ones of same group. Morphological studies were performed with the help of vernier calliper and goniometer.

\section{RESULTS}

The findings in the entire specimen of dissected feet were fundamentally the same with minor variations (Fig. 17). All of the tali were found to be distorted both in shape and orientation (Table I-VI). The talar articular surface of the ankle joint was less convex than normal. The talus was oriented in the ankle joint in plantar flexed position. The most conspicuous and only constant abnormality was found in anterior part of the talus. The neck of the talus was always short, which was markedly deviated medially and plantarward on the body and sometimes not identifiable, so that the head seemed fused directly to the body. The angle between the long axis of neck of the talus and long axis of
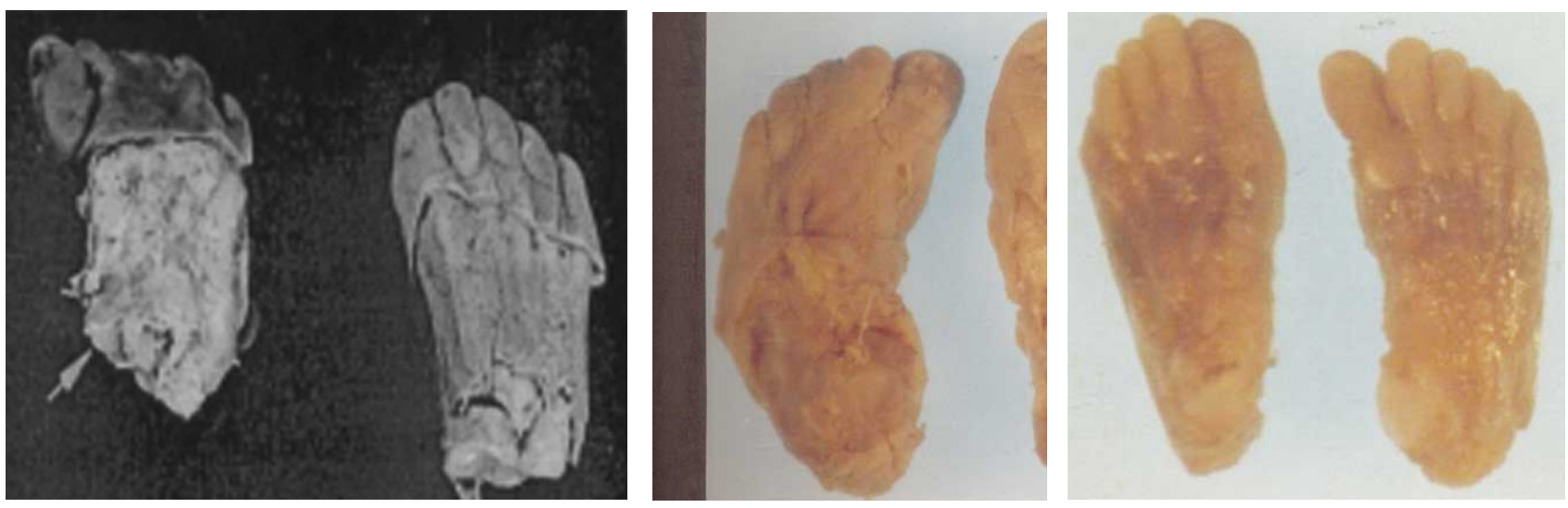

Fig. 1. Dissected feet with intact tali (A, B and C). The feet were removed through the talonavicular-calcaneocuboid joints and through tibiotalar joint. Relative shortening of the medial side of the club foot and the plantar inclination of its articulations to the hind part of the foot were observed in diseased foot.

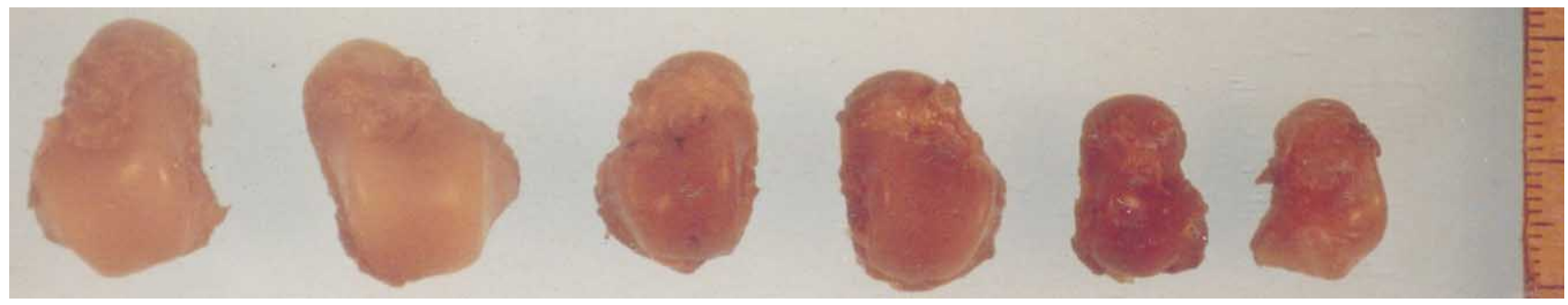

Fig. 2. Photographs of the disarticulated tali, dorsal view, showing deformity of the anterior portion of talus.

SUPERIOR

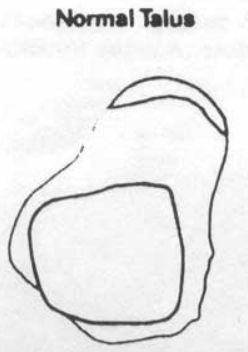

Club foot Talus
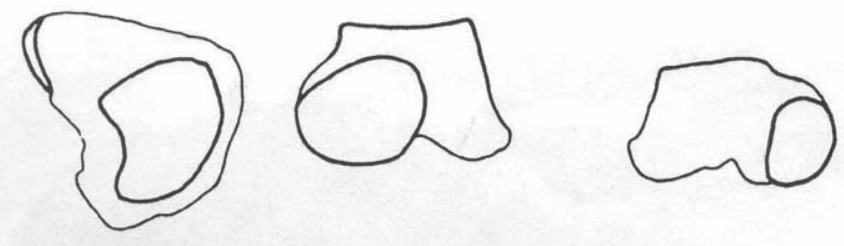

Fig. 3. Diagrammatic illustrations of the clubfoot and normal tali. 
the body was regularly and significantly decreased. In normal foot this angle varied from 150-155 degree, whereas in club feet it measured 115-135 degree. The navicular articular surface of the normal tali faced forward in the frontal plane of the body, but the corresponding surfaces of club foot tali faced medially and plantarward, so that the articular surface no longer faced directly forward. The body of the club foot talus was not as high as that of the normal talus, its superior articular surface was flattened, and its posterior surface was oblique. In all six club feet the medial deviation of the long axis of the neck related to the long axis of the trochlea was 40-50degree depending upon severity (normal value $25-28 \pm 10$ degree). There was a mild to moderate flattening of the trochlear articular surface. A reduction of the anterior part of the trochlear joints surface was also noted.

The calcaneus had in general a normal contour but appeared slightly smaller than normal. The calcaneus articulated with talus which faced posterior and medially and were rotated internally along with the distorted talar neck. The calcaneus was displaced into varus, equinus and internal rotation. In the diseased foot talonavicular and calcaneocuboid joint faced medially and plantarward because of talar deformity otherwise normally these were in the frontal plane of the body.

The navicular bone was smaller than normal size and its articulation with talus had varying degree of inclination or wedging toward the medial and plantar surfaces of the foot, thus increasing both the concave curve along the inner border of the foot and the plantar flexion deformity. This resulted in shortening of the medial border of the foot.

Fig. 6. A right talus from above. The medial deviation of the talar neck was determined by measuring the angle (A) between the axes of trochlea and neck. The medial deviation of navicular facet was expressed as the angle (B) between the axis of the trochlea and the baseline of the facet.

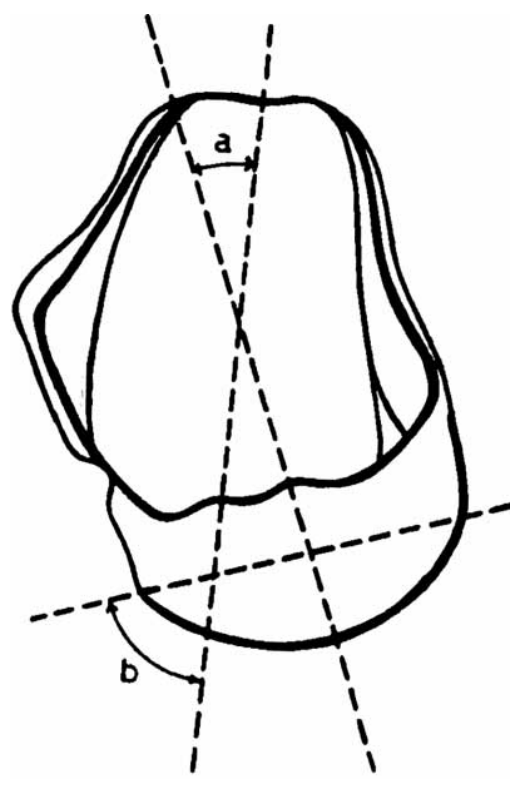

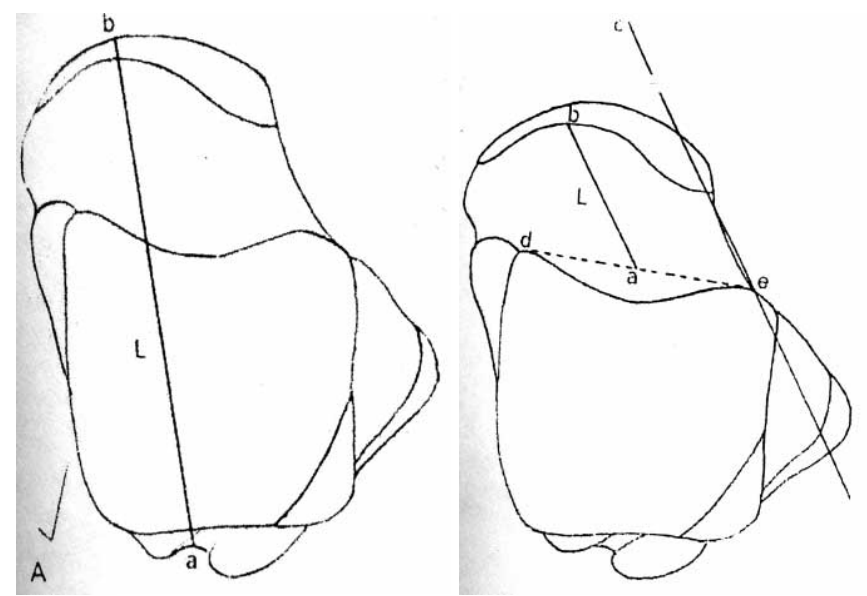

Fig. 4. Maximum length of talus (A) and talar neck length (B).

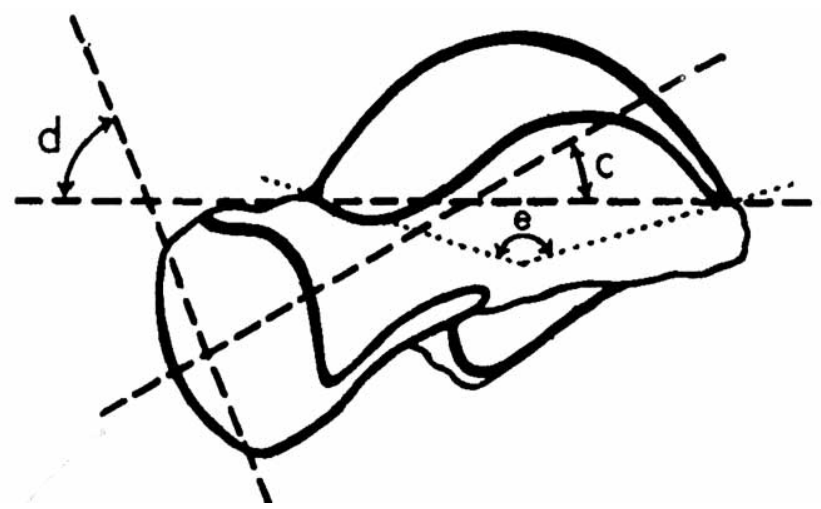

Fig. 5. Talus of right side observed from the medial aspect, showing plantar deviation of the neck using the angle(C) between the baseline of the trochlear and the axis of the neck. The plantar deviation of the navicular joint facet was measured by the angle (D) between the baselines of the troclea and the facet.

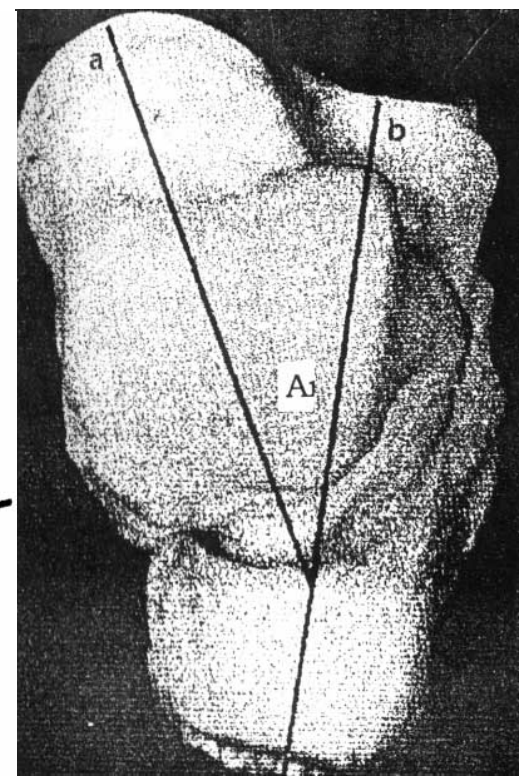

Fig. 7. Talocalcaneal angle (Dorsal view), determined by measuring the angle $(\mathrm{A})$ between long axes of calcaneum and talus. 
Table I. Talar neck and calcaneal angle (Degrees).

\begin{tabular}{|c|c|c|c|c|c|}
\hline \multirow[t]{2}{*}{ Sample } & \multirow[t]{2}{*}{$n$ of foetuses } & \multirow[t]{2}{*}{ Age (weeks) } & \multicolumn{2}{|c|}{ Measurements } & \multirow[t]{2}{*}{ p Value } \\
\hline & & & Normal (Mean \pm SD) & Abnormal Mean \pm SD & \\
\hline 1. & 06 & $23-25$ & $17.10 \pm 0.07$ & $16.20 \pm 0.08$ & $<0.0001$ \\
\hline 2. & 06 & $26-28$ & $16.65 \pm 0.04$ & $15.07 \pm 0.06$ & $<0.0001$ \\
\hline 3. & 06 & $29-30$ & $15.31 \pm 0.038$ & $12.53 \pm 0.17$ & Equal 0.0042 \\
\hline
\end{tabular}

Table II. Talocalcaneal angle (Degrees).

\begin{tabular}{lccccc}
\hline Sample & $\mathrm{n}$ of foetuses & Age (weeks) & \multicolumn{3}{c}{ Measurements } \\
\cline { 3 - 5 } & & & Normal (Mean \pm SD) & Abnormal Mean \pm SD & \\
\hline 1. & 06 & $23-25$ & $8.20 \pm 0.20$ & $6.09 \pm 0.06$ & Equal 0.0012 \\
2. & 06 & $26-28$ & $16.44 \pm 0.058$ & $10.73 \pm 0.136$ & Equal 0.0012 \\
3. & 06 & $29-30$ & $18.71 \pm 0.05$ & $10.59 \pm 0.115$ & Equal 0.0260 \\
\hline
\end{tabular}

Table III. Maximum length of talus (mm).

\begin{tabular}{lccccc}
\hline Sample & $\mathrm{n}$ of foetuses & Age (weeks) & \multicolumn{3}{c}{ Measurements } \\
\cline { 3 - 5 } & & & Normal $($ Mean \pm SD) & Abnormal Mean \pm SD & \\
\hline 1. & 06 & $23-25$ & $19.43 \pm 0.136$ & $15.45 \pm 0.137$ & Equal 0.0413 \\
2. & 06 & $26-28$ & $16.36 \pm 0.121$ & $11.41 \pm 0.116$ & $<0.0001$ \\
3. & 06 & $29-30$ & $13.08 \pm 0.098$ & $9.31 \pm 0.11$ & Equal 0.0037 \\
\hline
\end{tabular}

Table IV. Longitudinal dimension of head (mm).

\begin{tabular}{lccccc}
\hline Sample & n of foetuses & Age (weeks) & \multicolumn{3}{c}{ Measurements } \\
\cline { 3 - 5 } & & & Normal $($ Mean \pm SD) & Abnormal Mean \pm SD & \\
\hline 1. & 06 & $23-25$ & $3.68 \pm 0.172$ & $2.76 \pm 0.121$ & $<0.0001$ \\
2. & 06 & $26-28$ & $7.08 \pm 0.116$ & $4.6 \pm 0.126$ & $<0.0001$ \\
3. & 06 & $29-30$ & $9.26 \pm 0.103$ & $6.1 \pm 0.126$ & Equal 0.0021 \\
\hline
\end{tabular}

Table V. Anterior trochlear breadth ( $\mathrm{mm})$.

\begin{tabular}{lccccc}
\hline Sample & $\mathrm{n}$ of foetuses & Age (weeks) & \multicolumn{3}{c}{ Measurements } \\
\cline { 3 - 5 } & & & Normal (Mean \pm SD) & Abnormal Mean \pm SD & \\
\hline 1. & 06 & $23-25$ & $3.41 \pm 0.098$ & $2.7 \pm 0.109$ & Equal 0.0114 \\
2. & 06 & $26-28$ & $6.3 \pm 0.126$ & $4.56 \pm 0.121$ & Equal 0.0089 \\
3. & 06 & $29-30$ & $9.25 \pm 0.137$ & $6.25 \pm 0.137$ & Equal 0.0021 \\
\hline
\end{tabular}

Table VI. Maximum medial talar heights ( $\mathrm{mm})$.

\begin{tabular}{lccccc}
\hline Sample & $\mathrm{n}$ of foetuses & Age $($ weeks $)$ & \multicolumn{3}{c}{ Measurements } \\
\cline { 3 - 5 } & & & Normal $($ Mean \pm SD) & Abnormal Mean \pm SD & \\
\hline 1. & 06 & $23-25$ & $3.23 \pm 0.103$ & $2.31 \pm 0.116$ & Equal 0.0004 \\
2. & 06 & $26-28$ & $7.38 \pm 0.132$ & $5.48 \pm 0.098$ & $<0.0001$ \\
3. & 06 & $29-30$ & $9.33 \pm 0.081$ & $5.23 \pm 0.150$ & Equal 0.0005 \\
\hline
\end{tabular}

\section{DISCUSSION}

Previous investigations (Adams, 1855; Parker \& Shattock; Nichols, 1897; Irani \& Sherman; Settle, 1963;
Reimann, 1967) have shown a varying degree of skeletal deformity in club feet. 
The unilateral club foot allowed comparison between a normal and an abnormal talus in the same foetus. The most pronounced deformity, however, concerned the head and neck of the talus, which to a varying extent deviated medially and plantarly. The trochlea of the talus might have an apparently normal form but also was flattened and showed a reduction of the front part of its tibial articular surface as well as reduction of its malleolar articular facets. The more or less deformed navicular bone is subluxated medially and plantarly with a corresponding deformation of the articular facet of the talar head. Thus our dissection study confirmed previous observations concerning the skeletal deformities.

A unilateral prevalence of club foot in our fetuses promoted the intrauterine mechanical pressure a mere predisposing factor leading to club foot deformity. This might be secondary to other primary reasons, e.g. intrauterine crowding (supported by a significantly higher incidence of club foot among twins compared to singleton birth), foetalpelvic disproportion, decreased foetal movements etc.

ACKNOWLEDGEMENT. Authors are thankful to the Department of Anatomy, Jawaharlal Nehru Medical College, Aligarh Muslim University for providing facilities.

FAZAL-UR-REHMAN \& FARUQUI, N. A. Cambios morfométricos en talus del pie zambo, una observación macroscópica en fetos humanos. Int. J. Morphol., 30(1):217-221, 2012.

RESUMEN: Para su estudio morfológico fueron disecados ambos pies de seis fetos humanos de distintas edades, uno de los pies era zambo. Seis parámetros morfométricos fueron considerados para la comparación de graves alteraciones anatómicas en los pies normales y deformes; estos fueron: 1. Longitud máxima del talus, 2. Dimensión longitudinal de la cabeza del talus, 3. Ancho troclear anterior, 4. Altura medial máxima del talus, 5. Cuello talar y ángulo calcáneo, 6. Ángulo talocalcáneo. Todos los fetos con pie zambo congénito tienen una deformidad similar del esqueleto del pie. Las anomalías graves observadas fueron el menor tamaño del talus del pie zambo, aumento de la desviación media y retraso en el crecimiento plantar, deformación de la cabeza y región del cuello talar. También se observó una subluxación medial plantar del hueso navicular, con un consecuente deformidad de las facetas articulares de la cabeza del talus. La uniformidad y consistencia de las anomalías anatómicas fueron los rasgos más llamativos en este estudio.

PALABRAS CLAVE: Pie zambo; Talus; Morfometría; Fetos humanos.

\section{REFERENCES}

Adams, W. Double Talipes Varus, and Sina bifida in a fetus at birth; also, The Bones of the foot from an Adult Affected with Congenital Talipes Varus. Trans. Pathol. Soc. London, 3:455-64, 1852.

Adams, W. A Series of four Specimens Illustrating the Morbid Anatomy of Congenital Club-foot (Talipes varus). Trans. Pathol. Soc. London, 6:348-57, 1855.
Bechtol, C. O. \& Mossman, H. W. Club Foot. An Embryological Study of Associated Muscle Abnormalities. J. Bone Joint Surg. Am., 32:827-38, 1950.

Bohm, M. Thee Embryologic Origin Of Club Foot. J. Bone Joint Surg. Am., 11:229-59,1929.

Browne, D. \& Sydney, M. B. Talipes Equino-Varus. Lancet, 227:96974, 1934.

Dunn, P. M. Congenital postural Deformities: Perinatal Association. Proc. R. Soc. Med., 65:735-8, 1972.

Dunn, P. M. Congenital postural Deformities. Br. Med. Bull., 32:71-76, 1976.

Flinchum, D. Pathological Anatomy in Talipes EquinoVarus. J. Bone Joint Surg. Am., 35-A:111-4, 1953.

Irani, R. N. \& Sherman, M. S. The Pathological Anatomy of Club Foot. Clin. Orthop. Relat. Res., 84:14-20, 1972.

Kaplan, E. B. Comparative Anatomy of Talus in relation to the Idiopathic Clubfoot. Clin. Orthop. Relat. Res., 85:32-7, 1972.

Keith, A. Human Embryology and Morphology. $6^{\text {th }}$ ed. Baltimore, Williams and Wilkins, 1948.

Nichols, E. H. Anatomy of Congenital Equino Varus. Boston Med. Surg J., 136:150-3, 1897.

Parker, R. W. \& Shattock, S. G. The Pathology and etiology of Congenital Club Foot. Trans. Pathol. Soc. London., 35:423-44, 1884.

Reimann, I. Congenital Idiopathic Club Foot; with special reference to the etiology, pathogenesis, and possibilities of correction within the first year of life. Copenhagen, Munksgaard, 1967.

Settle, G. W. The Anatomy Congenital Talipes EquinoVarus: Sixteen dissected specimens. J. Bone Joint Surg. Am., 45-A:1341-54, 1963.

Siegel, M. I. Letters: Reply to 'comparative anatomy of the talus in relation to idiopathic club foot'. Clin. Orthop. Relat. Res., 102:26870, 1974.

Stewarts, S. F. Club Foot: Its incidence, cause and treatment. An Anatomical- Physiological Study. J. Bone Joint Surg. Am., 33A:577-90, 1951.

\section{Correspondence to: \\ Fazal-ur-Rehman \\ Department of Anatomy \\ Jawaharlal Nehru Medical College \\ Aligarh Muslim University \\ Aligarh 202002, (U.P.) \\ INDIA \\ Received: 11-07-2011 \\ Accepted: 18-08-2011}

Email: fazal.rehman72@yahoo.com 